\title{
Development of maritime Trade Polities and diffusion of the "South China Sea Sphere of Interaction pan-regional culture": The Khao Sek excavations and industries' studies contribution
}

\author{
B. Bellina
}

\section{Introduction}

The notion of an integrated Southeast Asian space has long been advocated by Braudel-inspired historians such as Anthony Reid, who argued that long-established interconnections within the South China Sea likely extending back to prehistory account for the region's strong spatial and human integration (Reid, 1988: 1-10). And indeed, studies now pulling together archaeological sciences, genetics and linguistics provide accumulating records of sustained networks through which desired artefacts were shared by the late Pleistocene, ca. $\sim 20$ kya (Bellwood, 2007; Blench, in press; Brandão et al., 2016; Bulbeck, 2008; Soares et al., 2008, 2016). In parallel, the Bay of Bengal has also been increasingly understood as a unifying space within which littoral populations had been knitting relations and developing shared cultural references (Amrith, 2013) as early as the late prehistoric period (in Southeast Asia) and the early historical period (in South Asia) (Kulke, 1990), and perhaps as early as the Neolithic (Gupta, 2005).

As a natural crossroad between these two basins, the Thai-Malay peninsula developed ports from the mid-first millennium BCE. These became meeting places for merchants, religious men and mariners staying there waiting for the change of monsoon. They also developed into large industrials centres, receiving materials and technologies, hosting foreign artisans and producing hybrid goods (Bellina et al., 2014). These port-settlements developed as favoured cultural cradles within which culturally hybrid concepts and products were elaborated and diffused in both maritime basins. During this period, several communities along the South China Sea came to share a set of desirable goods such as Dong Son drums, Sa Huynh-Kalanay-related ceramics, nephrite lingling-o, carnelian and glass beads, high-tin bronze bowls, etc. (Bellina, 2001, 2007; Bellina, in press-a, b, d; Glover, 2015; Hung et al., 2013; Solheim, 2006). Except for Sa Huynh-Kalanay ceramics, those goods were interpreted as mere imports until a decade ago when technological analysis began to suggest that some of the emblematic ones, the hard stone ornaments, were made locally with foreign techniques and adapted to local taste (Bellina, 2001, 2007). Since then, research has generated increasing evidence that these widespread objects were most often locally made, combining imported motifs and shapes (Flavel, 1997), exotic materials (Carter, 2015; Carter and Dussubieux, 2016; Hung and Bellwood, 2010; Hung, in press) and skilled exogenous techniques that originated in South Asia and East
Asia (Bellina, 2001, 2003, 2007; Bellina et al., 2012; Bouvet, 2011; Dussubieux and Bellina, in press; Favereau, 2015; Favereau and Bellina, 2016; Pryce et al., in press). The hybrid nature of these products reveals that social and political interactions within and between societies of the two sea basins during late prehistoric periods were much more complex and dynamic than expected. In addition to industries, one might consider the possibility that as early as this period, similar processes of cultural hybridisation may already have influenced urban conceptions across the South China Sea region (Bellina, in press-a, b).

Traditionally, both in South and in Southeast Asia, the study of the development of early states and cities has predominantly concerned large-scale agrarian polities. In contrast, much less consideration has been given to the political organisation and the forms of urbanism that smaller coastal polities developed along the littorals of the two sea basins during the late first millennium BCE and the first millennium CE (Bellina (in press-b)). Southeast Asian port-cities have been well described for the historical period (Lombard, 1970, 1988; Miksic, 2000; Reid, 2000). The prehistoric and early historical port-of-trade forms of urbanism remain to be revealed. As an example, I have argued that the cosmopolitan walled port of Khao Sam Kaeo in the Thai-Malay Peninsula was an early urban settlement whose configuration may relate both to coastal South Asian and Southeast Asian traditions (Bellina (in press-a)). This and other prehistoric coastal trading polities developed complex political and urban configurations at the same time as other Southeast Asian land-based emerging states (Bellina (in press-a)) such as at Co Loa (Kim, 2013, 2015) and at Angkor Borei (Stark, 2006, 2015), in what is now Vietnam and Cambodia, respectively.

This special issue provides new lines of evidence to characterise these emergent complex settlement and political forms exemplified by the trading polities of the late prehistoric Thai-Malay peninsula. This paper compares two neighbouring and contemporaneous mid- to late first millennium BCE early ports-of-trade located in the Kra Isthmus: Khao Sek and Khao Sam Kaeo (Chumphon province, Thailand). Both developed comparable settlement and similar industrial patterns that produced several of these above-mentioned pan-regional types of products (Map 1). This article summarizes data from settlement excavations carried out at Khao Sek by the Thai-French Archaeological Mission in 2013 and 2014 and from technological reconstructions of different onsite industrial systems, in the context of our earlier findings from the port of trade of Khao Sam Kaeo (excavated 2005 to 2009; 


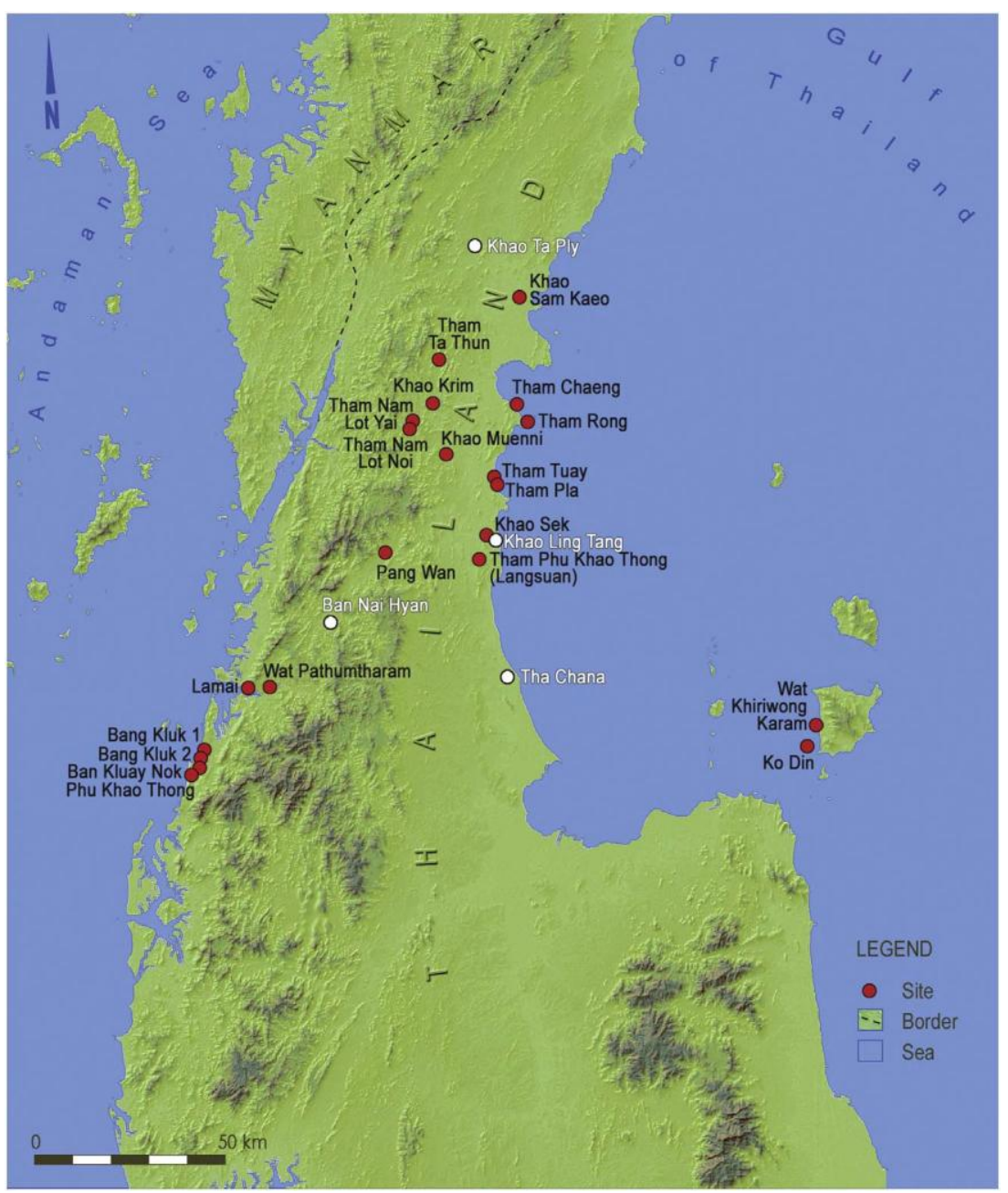

Bellina, in press-d; Bellina, 2014). The papers that follow compare the Khao Sam Kaeo and Khao Sek hard stone, glass, copper-based, ceramic technological systems as well as an iron workshop, each representing hybrid industries that involved complex foreign technologies.

I first provide general background on the shared material items found along the shores of the South China Sea that were generated or exchanged by the inhabitants of Metal Age polities. There follows two brief overviews: the first of the political models usually used to describe historical maritime polities in Southeast Asia - socio-political configurations which some historians believe to have crystallised from the western South China Sea Metal Age maritime polities but whose study is still undeveloped. The second overview presents the current state of art of early port-polity archaeology in Southeast Asia. The article proceeds with a presentation of the results of Khao Sek excavations and of its industries' analysis, revealing both similarities and differences with Khao Sam Kaeo, specifically that Khao Sek is smaller and less complex. Bringing these settlement and craft systems analyses together, the paper hypothesises a political model of a confederation of complementary and also, most likely, at times competing trade polities that sought to control both maritime and transpeninsular routes and argues that this model explains the regional diffusion of craft systems and shared material culture within the "South China Sea Sphere of Interaction".

\subsection{Pan-regional material culture exchange and production}

Metal Age shared material culture mainly found along the coasts, but also inland in lesser quantity, includes ornaments in stone, glass and metal, Dong Son drum bronze drums, bronze flasks, high-tin bronze bowls and ceramics. Some are now well-dated to the late first millennium BCE; others suffer from a less-precise chronology (such as the bronze flasks). These items present three configurations: locally-produced objects made with local techniques and imported style, such as is the case for most "Sa-Huynh-Kalanay" related ceramics (Bellina et al., 2012; Favereau and Bellina, 2016; Flavel, 1997; Favereau, 2015; Solheim, 2006); imported artefacts, such many Dong Son bronze drums, whether imported from northern Vietnam or from other production sites in Southeast Asia, such as at Non Nong Hor in Northeastern Thailand (Calo, 2014; Sukanya Baonoed, 2016); and finally, locallyproduced objects implementing complex foreign techniques and imported raw materials, such as in the case of several ornaments and metal objects, many of which cannot be clearly associated to a specific region (to cite only a few: Bellina, 2007; Carter, 2015; Dussubieux and Gratuze, 2010; Hung et al., 2007, 2013; Murillo-Barroso et al., 2010; Pryce et al., in press).

On what basis were these items exchanged? It is hypothesised that the most likely mode was barter and gift-giving (Bellina and Glover, 2004). What may have been the social and political or possibly religious dynamics underlying the exchange of these commonalties during the late prehistoric period? Some have proposed a potential ritual or religious dimension, with a trading network of ritual exchange comparable to the "Kula" ring (Blench, in press)? Others envisaged a wide politico-religious system within which Dong Son drums were regalia that local chiefs in various parts of Southeast Asia sought to become kings (Loofs-Wissowa, 1991). The nephrite lingling-o and doubleheaded ornaments found in Sa Huynh communities have been interpreted as the vehicles in a religious network (Dung, 2017). A more 
secular view proposes that goods such as the Dong Son drums materialised alliances between trade-linked polities (Calo, 2014). Along similar lines, Junker in the Philippines and Bellina in the Thai-Malay peninsula, have argued that those exchanged goods were used for structuring and maintaining alliances necessary for conducting exchange and for strengthening bonds with allied polities to increase power in periods of warfare (Junker, 1993; Junker, 1990; Junker, 1999; Bellina, 2007, 2014; Bacus, 2003). Ties were woven with less complex groups in the inlands or the maritime world that provided the raw materials and goods needed for long-distance trade (Bronson, 1977; Wisseman Christie, 1990), as well as with similarly complex socio-political systems (Wolters, 1982). In the latter case, these shared culturally

hybrid objects could reflect shared socio-political practices and exemplify the manner by which foreign innovations were deemed useful for socio-political strategies, and how they were adapted and participated in trading elite groups' social identity construction (Bellina, 2014).

What may have been the social and political meanings of the production systems generating those highly symbolic goods? Both Junker and Bellina have interpreted them as patron-promoted crafts for building instruments of power and prestige for trading elites (Junker, 1990, 1993, 1999; Bellina, 2001, 2007, 2014). But craft products were not only a political currency, so too was the system. In the framework of likely peer-polity types of interaction, I suggest that leaders' prowess in late prehistoric polities was probably increased by controlling skilled labour and craft systems in particular (Bellina, 2007, 2014). Southeast Asia provides historical examples of raids of artisans, who "enslaved", participated in their new leader's prestige and cultural exchanges (Beemer, 2009).

\subsection{Political models and Metal Age ports-of-trade}

In all of the models developed to describe Historical Southeast Asian kingdoms' socio-political organisation, the leader's charisma is crucial for the polity's good fortune. Leadership was built on the idea that some individuals were gifted with extraordinary qualities that enabled them to sustain relationships with gods or spirits. Leadership, understood in personal and ritual terms, needed constant confirmation as the system was held together by a complex system of loyalty. This was essential in traditional Southeast Asian kingdoms which consisted of coalescent partly autonomous centres (Tarling, 1992: 402-409).

Two main models have been applied to the early Southeast Asian political landscape. The "Mandala" model proposes a central polity with radiating influences that decline with distance from the centre and emphasises the non-physical character of the system. The second model proposes a hierarchic upstream-downstream river-based system.

"Mandala" is a Sanskrit word used in Indian political manuals; it was employed by O. Wolters (1982) and H. Kulke (1986) to describe the sort of political system also called "galactic polity" by S.J. Tambiah (1977) or "Solar polity" by V. Lieberman (2003). The "Mandala" model and its analogues describe a confederation of kingdoms or polities subordinate to a centre of domination. At the core of the system is a ruler "claiming divine and universal authority (...) able to maintain hegemony and counter potential rivals by building up a system of alliances with surrounding kings" (Andaya and Andaya, 2015: 46). In the Thai-Malay peninsula and Island Southeast Asia (Java and Bali excluded), the fragmented nature of the geographic environment was conducive to similarly dissected political systems that challenged any centralised control and sustained alliances over a large territory (Andaya and Andaya, 2015: 46). At times, alliances could cement small polities into a hierarchical confederation. However, competition for the control of trading routes can easily turn into conflicts, dissolving the federation and leading to the creation of new alliances and revamped federations. The "multiplicity of political centres and shifting loyalties of their leaders, particularly at the periphery of their system" (Kulke, 1986: 7) are essential features of the "Mandala" political system of early
Southeast Asian kingdoms. The hierarchical relationships that a dominating polity's leader had to maintain with other neighbouring polities were hence very precarious, resulting in a trend for the Mandala to "expand and contract in concertina-like fashion" (Wolters, 1982: 1617). Polities located at the periphery of the central place could ea- sily switch their loyalty towards another polity with the ambition to become a central place, producing an unstable political environment. Because of this multiplicity and instability, early competing coastal polities' rank relative to one another fluctuated in an evanescent manner depending on the period and the context; and any polity may have been involved in different networks, being "vassal" to two central places.

The second model invoked in Island Southeast Asia and in the ThaiMalay Peninsula is the hierarchic upstream-downstream river system model (Bronson, 1977). Initially, Bronson developed a model whereby a central place located downstream controlled the flux of goods entering or leaving a single river basin and which developed ties with a series of upstream secondary and tertiary centres. The port-city had to establish and maintain relationships with upstream societies to access hinterland productions. In exchange, these upstream populations benefitted from this overseas trade which gave them access to marine and imported prestigious items. These relationships may be understood as inter-dependent or symbiotic and explain some sort of economic specialisation of the various populations present on those lands. Malay texts and inscriptions make it clear that the port-city territory consists less of territory than of the network of relationships (Manguin, 2000: 412-4). Based on archaeological research, in particular on Srivijaya and Malacca and a reappraisal of Malay sources, Manguin later introduced the idea of the "multi-centred coastal polity" in which the central place is surrounded by an "umland"/periphery", i.e. a wider « hinterland » fed by its riverine and maritime network. In this version of the model, the downstream polity could encompass more than one river system and, as may have been the case for Srivijaya, different river systems may have fed the primary central place which alone operated at a larger scale, selling to merchants all the products coming from its regional networks. This system worked by conferring a vassal status on series of polities that themselves once might have been central places. However, in many cases, these may have been temporary vassals that had the potential to expand again according to a leader's ambition. In this revised model, as in the case of Srivijaya whose central place changed location over time, a polity may be multi-centred and its centre unfixed. The central place hosted the ruler (raja) who also functioned as the symbolic centre of the polity's space (Manguin, 2002).

Several historians of maritime polities hypothesised that these socio-political configurations crystallised during the Late Prehistoric Period (Andaya, 2008; Manguin, 2000, 2004; Wisseman Christie, 1995). However, research on Metal Age port-polities' organisation remains scarcely explored, leaving these assumptions to be grounded. Besides the seminal works of J. Wisseman Christie and Leong Sau Heng's (Wisseman Christie, 1984/5, Wisseman Christie, 1990, Wisseman Christie, 1995; Leong Sau Heng, 1990), the social and political organisation of prehistoric trading-polities' has barely been investigated in Southeast Asia, lagging behind scholarship on early centuries CE mainland early polities such as Oc Eo and Angkor Borei in the Mekong delta part of the Funan polity (Bourdonneau, 2010; Manguin and Khai, 2000; Manguin, 2004; Stark, 2006), Go Cam of the polity of Linyi and Tra Kieu the ancient capital of Champa in Central Vietnam (Yamagata and Glover, 1994; Yamagata, 1997, 2007). This is due to the dearth of excavation of settlements (hence ports-of-trade) and to the unappealingly poor remains they often leave in maritime settings (Junker, 2006). As a corollary, the dearth of excavations results in the absence of regional archaeological maps. To fully characterise the political structures of incipient states, it would be necessary to document and then compare several polities of similar and distinct ranks. It has been suggested that during the last centuries BCE, Late Prehistoric producer-trading incipient states in peninsular Malaysia and Sumatra 
may already have been involved in the exploitation and distribution of local resources for regional demand (Miksic, 1979: 255; Wisseman Christie, 1995; Manguin, 2002). Wisseman Christie thus proposed that Metal Age Malaysian peninsular lowland polities had already established relationships with upstream groups exploiting gold in exchange for lowland products during the last centuries BCE and the very early centuries CE (Wisseman Christie, 1990). This scenario would fit the late prehistoric incipient city-state of Khao Sam Kaeo quite well, in particular the exploitation of tin from the hinterland (Pryce et al., in press; Bellina, in press-d).

Late prehistoric sites providing evidence for their involvement in long-distance networks are found in the Thai-Malay peninsula, on the east coast of southern Sumatra (Manguin, 2009), the north coast of Java and Bali (Bellwood, 2007; Calò, 2015) and the central and southern coasts of Vietnam. However, except in the Thai-Malay Peninsula and Sumatra, none of these Metal Age sites are settlements, thus restricting the analysis of the polity/ies they were associated with. Early historical trading polities associated with settlements have recently been excavated in Peninsular Malaysia and in Sumatra. Harbour structures and iron producing workshops found of Sungai Batu in Kedah (Malaysia) provide evidence of already well-developed trading polities in the early first centuries CE (Mokhtar Naizatul Akma Mohd, 2009; undated). The pre-Srivijayan settlement of Air Sugihan on the south-eastern coast of Sumatra also yielded early first millennium remains of structures on poles and trade-associated artefacts showing similarities with material from Oc Eo in Vietnam (Agustijanto, 2013).

The study of the historical political structure of maritime historical kingdoms, both for the mandala and upstream-downstream models (and their various derivations), has relied mainly on data coming from texts, epigraphic sources, temple sites, and a small number of preserved archaeological artefacts such as imported ceramics and glass beads (Kulke, 1993; Manguin, 2002; Miksic, 1979). But for the Late Prehistoric period, the absence of epigraphic texts - other than the too shorts texts on seals-and the dearth of regional settlement maps prevent a comparable analysis. L.L. Junker's studies of later mid-first millennium CE Philippines polities, through an in-depth analysis of settlement hierarchies, port industries and their spatial distribution represents a type of research which is still very rare. The rich protohistoric industrial complex of Oc Eo supposedly associated with the early state of Funan has unfortunately not been subjected to an in-depth and systematic technological analysis or detailed studies of spatial distribution. Similarly, the port-industry found at Khlong Thom/Khuan Lukpad in southern Thailand was certainly associated with a polity but archaeological investigations did not identify it (Bronson, 1990; Veraprasert, 1992).

The technological reconstruction of socio-technological systems of the industries established in ports as well as the documentation of regional archaeological distributions are at the core of the Thai-French Archaeological Mission's research on the developments that took place during the Late Prehistoric period in the Kra Isthmus. This period witnessed the development of several port-industries, some formally identified, others yet to be discovered, and still others gone with the lootings (e.g. in the Tha Chana area). So far, three port-industries (bead making, copper metallurgy...) associated with two of these early trade polities have been identified. Khao Sam Kaeo (Bellina, in press-d) and Khao Sek benefited from intensive excavations; Phu Khao Thong from preliminary excavations and Ban Kluay Nok from survey (Boonyarit Chaisuwan, 2011; Bellina et al., 2014). The first three sites yielded evidence for the earliest large-scale port-based industries so far identified in the South China Sea; those are especially well identifiable due to the spectacular collection of beads they yielded. Those sites are located at the two ends of fluvial systems, which besides allowing the upstream-downstream circulation, also formed part of transpeninsular routes that connected the Indian Ocean to the South China Sea. These trans-isthmian routes were used by merchants, travellers likely including religious and craft specialists that polities may have wished to control, guide and attract. It is likely that the attempt to control these routes and maintain profitable relationships with groups living along them may have influenced the structuring of the early peninsular trading polities. Remains of sites along these transpeninsular routes are especially tenuous and require sustained research. Currently, the stateof-art of the archaeological work does not provide a complete picture of the various groups present in the peninsula or of their socio-political structures during the late prehistoric period. The research of the ThaiFrench Archaeological mission in the Thai-Malay peninsula in the Kra Isthmus area attempts to fill this gap to understand how the various groups participated and evolved through time in relation to their involvement in long-distance exchanges. Connections between the various groups is indicated by the material culture-beads and metal objects in particular; however, at present the modalities and the frequency are questions that cannot be answered due to the lack of context for most materials. Nonetheless, interactions between various groups present in the peninsula and with those from South Asia and the South China Sea are clearly attested as early as the 5th-4th century BCE (Bellina, in press-d; Bellina et al., 2014; Favereau and Bellina, 2016; Bouvet, 2012). On the base of these attested connections, and considering afresh the radiocarbon dates available for the Thai-Malay peninsula during the Holocene, D. Bulbeck questioned whether a "South Asian-style Mandala form of polity (...) may have either been established at Khao Sam Kaeo before the Common Era, or operated as an ideological superstructure for emerging polities already equipped with local experience in managing maritime centres" (Bulbeck, 2014: 138). Khao Sam Kaeo and Khao Sek settlements and technological system analysis yield significant data to discuss Metal Age trade polities' structure in the Thai-Malay peninsula and the possible means by which pan-regional craft systems may have diffused.

\subsection{Khao Sek excavations main results}

Khao Sam Kaeo was excavated from 2005 to 2009. The walled cosmopolitan site lies along the River Tha Tapao and about $10 \mathrm{~km}$ from the South China Sea coastline (Bellina, in press-d; Bellina et al., 2014). Khao Sek has been intensively looted for several years before the ThaiFrench Archaeological Mission conducted excavations in 2013 and 2014. Some areas of the site (see Map 3) had been transformed by agricultural activities, such as the western slope of Hill 1 used for rubber plantation and the top of Hill 2, used for a papaya plantation. Others areas, such as the top of Hill 1 and its northern and eastern slopes were occupied by Buddhist structures. Finally, the westernmost area of the site along the shore, shown as a blank on Map 3, had been looted with industrial mining methods. This area corresponded to the harbour and was the location of stone and glass working industries.

Khao Sek shows several similarities to Khao Sam Kaeo despite being smaller and notably less complex. It is located $80 \mathrm{~km}$ south of Khao Sam Kaeo, in a similar environment, at a small distance from the current mouth of the large fluvial system of the River Langsuan. Research that the Thai-French Archaeological Mission has been conducting in the region since 2005 now clearly shows that the Langsuan River system was part of one of the earliest transpeninsular routes that linked the modern town of Langsuan where Khao Sek is located to Ranong via Pak Song (Phato District) (Map 2). The river's western portion is located on the tin-rich belt that crosses the peninsula from north to south. Tin mines were exploited until a few years ago and local villagers occasionally still pan in the river.

In two seasons at Khao Sek the Mission excavated $412 \times 2 \mathrm{~m}$ test pits (Map 3). They provide significant information on the extent of the site, its occupation, construction modes, organisation and the type of handicrafts it hosted.

\subsubsection{General configuration of Khao Sek}

The general configuration of the settlement appears comparable to Khao Sam Kaeo: the site is characterised by slightly elevated hills, 


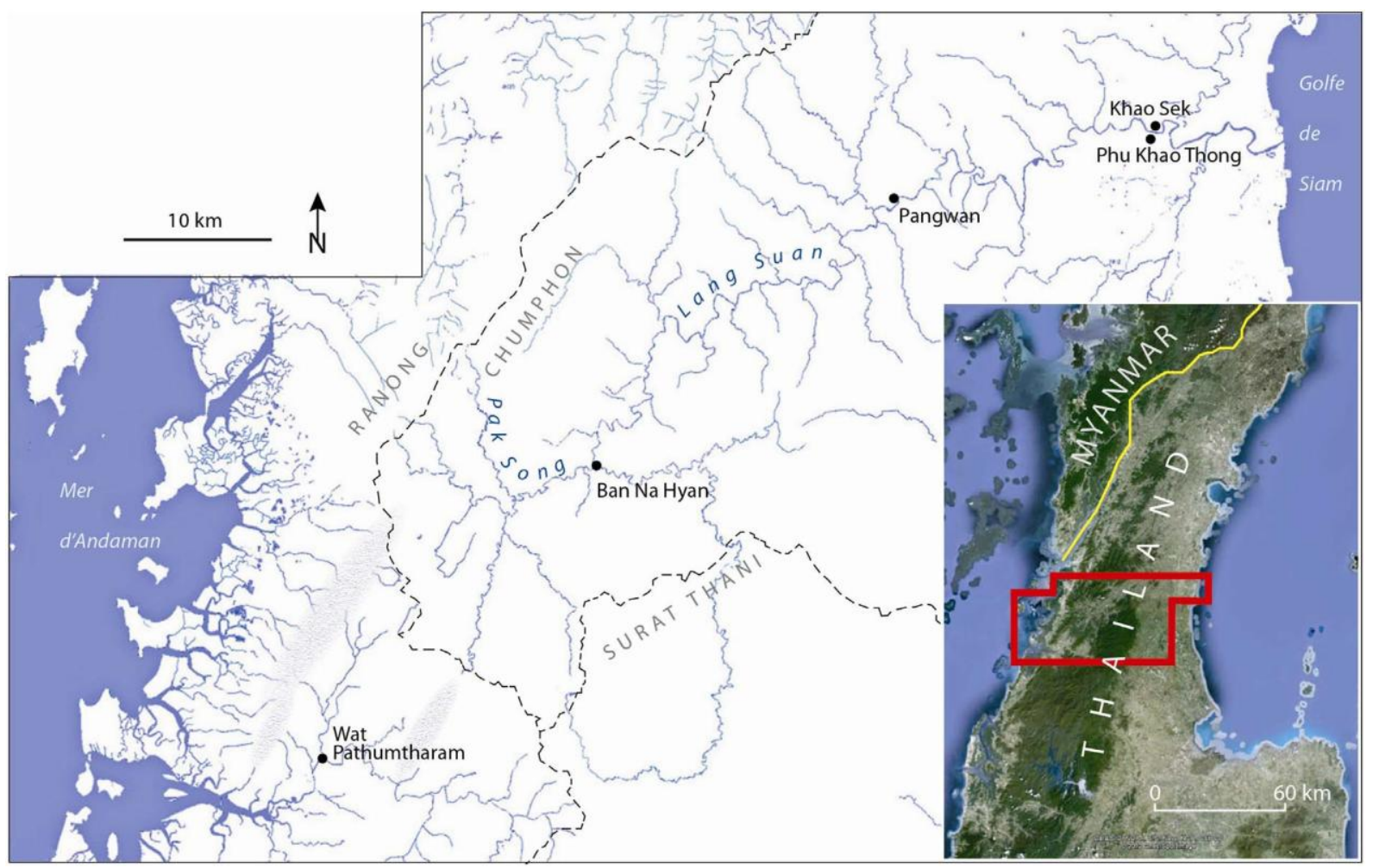

Map 2. The Langsuan River system covering the majority of this transpeninsular route and sites investigated by the Thai-French Archaeological Mission.

whose current height is around $90 \mathrm{~m}$ for the first hill and $50 \mathrm{~m}$ for the second, bordering the River Langsuan linking the site to the South China Sea (Map 3). The original topography of the hills has been altered. The top of the north-western part of Hill 1 has been modified by the construction of Buddhist monuments as well as by paths and stairs. The north-western and northern slopes of Hill 1 and the plateau of Hill

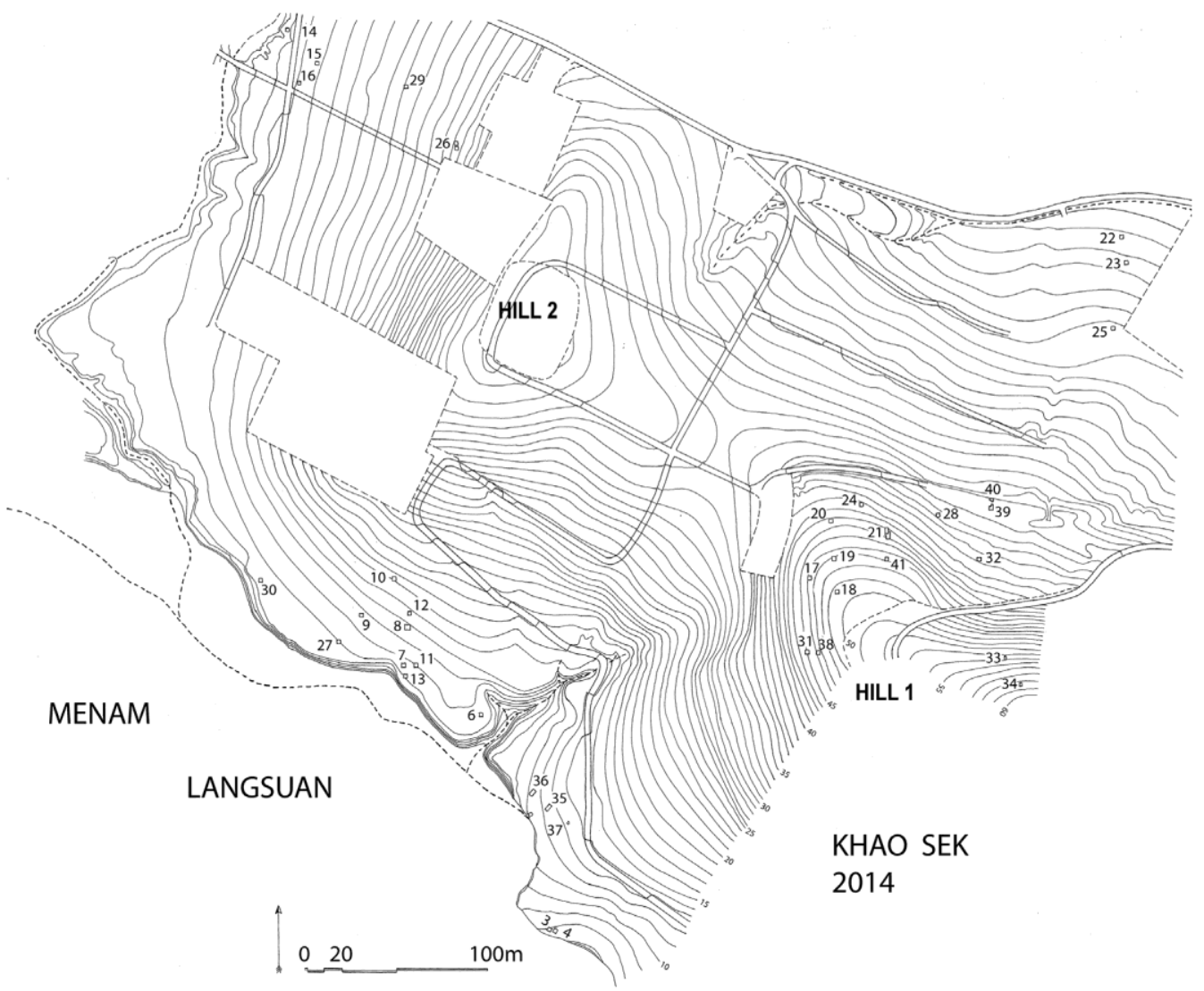

Map 3. Topographic map of Khao Sek locating 2013 (TP1 to 30) and 2014 (TP 21A to 31 to 40 ) test pits.

$\mathrm{N}$ 
2 have also been graded to receive rubber and papaya plantations. In addition, the topography of the site was modified by agricultural work and looting. Finally, here it is important to add that we have not had access to all the land, so our view of the site of the site and its occupation is partial.

Khao Sek is now about $8 \mathrm{~km}$ from the coast. We estimate that the maximum occupied area to about $450 \mathrm{~m}$ from east to west and $250 \mathrm{~m}$ from north to south. The occupation could thus extend over about 10 ha, which makes this site significantly smaller than Khao Sam Kaeo, with a conservatively estimated occupied area of about 35 ha.

More than at Khao Sam Kaeo, Khao Sek's hill slopes are heavily eroded; it is consequently difficult to evaluate the density of occupation. However, considering the quantity of material and the structures unearthed upslope and downslope (eroded material), it seems likely that Khao Sek occupation was as dense as in Khao Sam Kaeo.

Seven charcoal samples have been submitted for radiocarbon dating. Four correspond to the modern occupation of the site and three to the late prehistoric period. While three dates are not sufficient to establish a chronological sequence of the site, they nonetheless suggest an occupation at least partially contemporaneous to Khao Sam Kaeo, by the 4 th- 3 rd c. BCE.

\section{TP21a_US13 WK 39007 (AMS) $2228 \pm 25$ BP Cal 390-200 BCE TP21_US3 WK 36900 (AMS) $2208 \pm 30$ BP Cal 376-199 BCE TP7_US3 WK $36897 \quad 2240 \pm 31$ BP Cal 391-205 BCE}

Radiocarbon dates (AMS and conventional) of the Late Prehistoric Period at Khao Sek.

These dates are relevant to the material culture, in particular the glass and stone ornaments and the decorated high-tin bronze bowls.

Unlike Khao Sam Kaeo, Khao Sek has not provided compelling evidence for a surrounding earthen wall paralleled by a ditch. However, at the bottom of the north-eastern slope of Khao Sek, about $40 \mathrm{~m}$ north of TP28, a topographic irregularity of linear shape was observable. It is now largely covered by a path and continues to the east beyond a northsouth-oriented opening used as a drain. A quick cleaning of the opening and a test pit excavated in the middle of the pathway by Sachipan Srikanlaya (TP40) did not bring definitive evidence of its antiquity. Although equivocal, it is not impossible that the settlement had been surrounded by wooden palisades, another defensive system used by early Southeast Asian polities described by Chinese sources.

Unlike Khao Sam Kaeo, no communal structures such as large drains, monumental platforms or a hydraulic system were documented at Khao Sek. However, the taphonomic changes the site has undergone could explain these absences.

In contrast, domestic structures were built in a mode similar to that observed in Khao Sam Kaeo. Habitations were built on top of terraces constructed towards the upper part of the eroded bedrock. Two test pits (pits 26 and 33) illustrate this. Test pit 26 was opened in the upper part of the western slope of Hill 2 (Fig. 1). It yielded remains of a terrace raised to host a habitation. Remains of the construction consist of a drain (KK26a) and a posthole, a type of construction similar to Khao Sam Kaeo. A trench opened in the structure showed that it consisted of a terrace made of eroded bedrock placed so as to compensate for the slope. This structure lies directly on top of the red and compact bedrock. The terrace measured $4 \mathrm{~m}$ long (north-south) and $1,7 \mathrm{~m}$ wide (east-west). A depression in the upper part of the terrace (KK26a) was interpreted as a possible drain located at the back of the habitation. No artefacts were unearthed from this test pit.

\subsubsection{Agricultural regime}

Sampling for archaeobotanical remains was carried out in 2013 and 2014 in 10 test pits (TP7, 8, 10, 12, 21, 21A, 22, 26, 31). Preservation was very poor and showed major modern disturbance. More analysis needs to be conducted. Khao Sek differs from Khao Sam Kaeo where rice clearly emerged as the staple cereal, along with millet probably cultivated on the site and in its vicinity, and which complemented by horticulture (Castillo, 2013; Castillo et al., 2016; Castillo, this issue). Khao Sek yielded only a few evidence for rice with but not for millet. Khao Sam Kaeo yielded evidence of imported foodstuffs, which has not been found in Khao Sek.

\subsubsection{Industries}

Craft areas for hard stone (cornelian, agate, garnet) and secondary glass production (Dussubieux and Bellina, this issue) were concentrated in the southwestern part of the site (shown as a blank section on the topographic map) and along the river's bank, like at Khao Sam Kaeo. Unfortunately, these were heavily looted. However, analyses of samples of waste materials and finished products from these industries show very strong stylistic, technical and (for glass) compositional similarities with Khao Sam Kaeo. This almost perfect parallelism of the industrial models for stone (Bellina, this issue) and glass (Dussubieux and Bellina, this issue) at Khao Sam Kaeo and Khao Sek involving similar feeding networks technologies and style, led us to propose the possibility that artisans circulated between the two sites. These issues are discussed more in detail in the analysis of stone (Bellina, this issue), glass, (Dussubieux and Bellina, this issue) and ceramics (Favereau, this issue) craft systems.

Other industries took place on Khao Sek's hills. Those include metal working, including the production of copper-base metal and high-tin bronze using similar Indian-derived techniques, as well as the production of forged iron with what is currently the most ancient well-preserved remains of an iron working workshop in Southeast Asia (Petchey et al., this issue). Fragments of a decorated high-tin bronze bowl of Indian-inspired style similar to those found at Khao Jamook, Ban Don Ta Phet and Khao Sam Kaeo were found on the site by the land owner (Fig. 2). Lead isotope analysis of these bowls has established links between the high-tin bronze alloy used for bowls found at Ban Don Tha Phet, Khao Sam Kaeo and Khao Sek bowls and an ingot from Tilpi in West Bengal, even if the primary source remains unclear (Pryce et al., 2014; Pryce and Bellina, this issue). Technological analyses of specialized ceramics from both Khao Sam Kaeo and Tilpi have provided evidence for the production of high-tin bronze ingots. Indeed, the northern part of Khao Sam Kaeo yielded crucibles and moulds pointing towards the production of high-tin ingots and beyond, the transfer of Indian high-tin bronze technologies to local craftspeople (Murillo-Barroso et al., 2010). The resulting high-tin bronze was possibly employed locally for artefact production, but the presence of ingot moulds and of a high-tin bronze ingot strongly suggests that production was also oriented for exchange. As for stone and glass industries, we may conceive an early technological transmission from the northern sub-continent and the possibility that South Asian high-tin bronze specialists settled at Khao Sam Kaeo, exploiting the Peninsula's especially rich tin resource (Pryce et al., in press) and taking advantage from Southeast Asia abundant sources of copper.

Iron technology appears in Southeast Asia and at Khao Sam Kaeo, Khao Sek and possibly in the less well-dated site of Phu Khao Thong simultaneously. The technologies used in those sites appear similar and are quite rudimentary as opposed to other industries. They also appear to have taken place in similar contexts within the two settlements. Iron is also a good candidate for an Indian-influenced technology (Petchey et al., this issue).

Local and foreign-influenced pottery groups at Khao Sek are identical to those at Khao Sam Kaeo (similar fabrics, techniques and shapes) except for the notable absence of foreign imports such as Indian Fine Wares and Han-Chinese related ware (Favereau, this issue). Foreigninfluenced wares are also proportionally much more frequent at Khao Sam Kaeo than at Khao Sek. Because they are very rare and similar to those from Khao Sam Kaeo, Favereau suggests that they might have come directly from Khao Sam Kaeo.

Finally, Khao Sam Kaeo yielded about thirty seals, inscribed or 

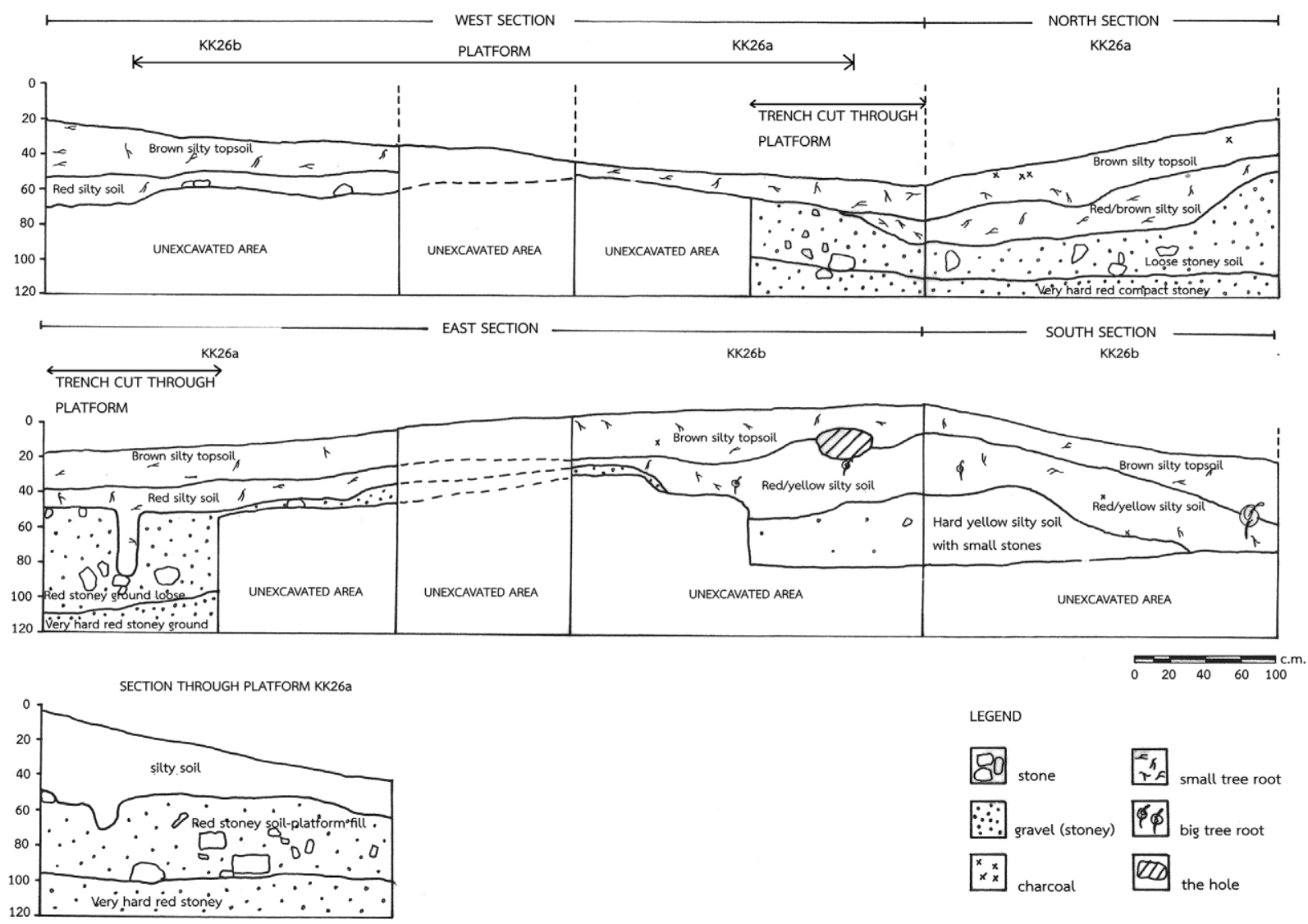

Fig. 1. Sections and plans of TP26 showing the built terrace and the posthole (drawing Jitlada Innanchai.

blank (Borell, in press). We know of only two seals at Khao Sek. As at Khao Sam Kaeo, both are Brāhmī inscriptions, giving the owner's name in the genitive and the language is Prakrit. Harry Falk, Professor of Indology at the Freie Universität in Berlin has examined these seals (personal communication) (Fig. 3).

The seal is made in a bi-colored stone and is $2,8 \mathrm{~cm}$ width and $3 \mathrm{~cm}$ height. Its writing is archaic and can be compared with the writing used during the reign of King Aśoka in the 3rd c. BCE. H. Falk's reading is śaghi-ya-śa. The name of the owner is spelt: a_śa_and not a _sa, a spelling found in various regions of Northern India. The shape of the seal is commonly found from the Ganges plains to Bengal. The symbol Namo (aka nandipada) is inverted (upside down), as it is often represented on ancient stupas where the symbol was made in stone as part of a necklace. The legend reads Samghiyasa and is the genitive form of Samghika as pronounced in Sanskrit. Samghika is probably an abbreviation of a personal name, like Saṃgharakșita or Saṃghadāsa. The seal is similar to a seal found in the Bhir mound in Taxila (Aman ur Rahman and Falk, 2011: 19xx). This seal should be compared to a seal from Bhir mound in Taxila where could be read as śidhathaśa for /siddhatthassa/ (Fig. 4).

Seal 2 is made of a dark brown stone and is $1,6 \mathrm{~cm}$ width and $2 \mathrm{~cm}$ height. Harry Falk (personal communication) described the person who engraved this seal as inexperienced, since "When printed the seal reads $\mathrm{x}$-dā-dhu-ba, which yields no sense. The letters when read from the seal read ba-dhu-de-x. B, dh and u in close proximity most likely were meant to express budha, Buddha that is. The transposition of the u-vowel from $\mathrm{b}$ to dh most likely came when the die-cutter wanted to reverse something as is necessary for a seal to print correctly. But instead of reversing all letters and incising them mirrorwise he left almost everything as he knew the letters. Reading _budhade_ leaves no choice but to complete to_budhadeva_, a personal name Buddhadeva. The last letter_va_ was incised upside-down. As it consists of a vertical over a circle, the circle close to the edge was cut away. Below: symbols as known from Mauryan punch-marked coins and an Aśokan moon-symbol, identical in form with a letter_ma_." This seal would correspond to an unskilled local production made by an inexpert artisan. Mistakes are sometimes found on seals in India, but never so critical, as emphasised by H. Falk.

In sum, the seal corpus at Khao Sek is of Indian-influence and of similar tradition as at Khao Sam Kaeo, but the corpus is much more modest.

\subsubsection{Funerary practices}

While some of the funerary practices documented at Khao Sek parallel those at Khao Sam Kaeo (such as the jar buried under a habitation), the interlocking of two ceramics (TP7) appears to be a unique practice which adds to the range of practices observed archaeologically in the Upper Thai-Malay Peninsula. As at Khao Sam Kaeo, it seems that funerary deposits were concentrated in the area bordering the river (TP7, 11 and 13). These consisted of a funeral urn (TP7) and the potential remains of two urns (TP11 and 13).

The burial in TP7 (Fig. 5) consisted of an urn deposit (US3-3). It was found below US1, between 8,70 and 9,04 $\mathrm{m}$ in the south-western corner of the square. The jar was of a foreign manufacture called Black-andRed Jars (at Khao Sam Kaeo the "KSK-BRJ" see Bouvet, 2011, in press and at Khao Sek the "KK-BJR" see Favereau, 2015, this issue) and was placed within another jar (US3-1). This urn did not yield any human remains or ashes. However, it contained a glass bead as well as fragments of a decomposed copper-alloy bracelet whose diameter could be estimated to about $5-6 \mathrm{~cm}$. The presence of an additional potential jar burial found in TP11 located four metres north of TP7 could indicate that this zone may have been used as a cemetery. Khao Sam Kaeo also provided urn deposits, some containing cremated remains of children whilst others were found empty. There, a zone located at the bottom of 


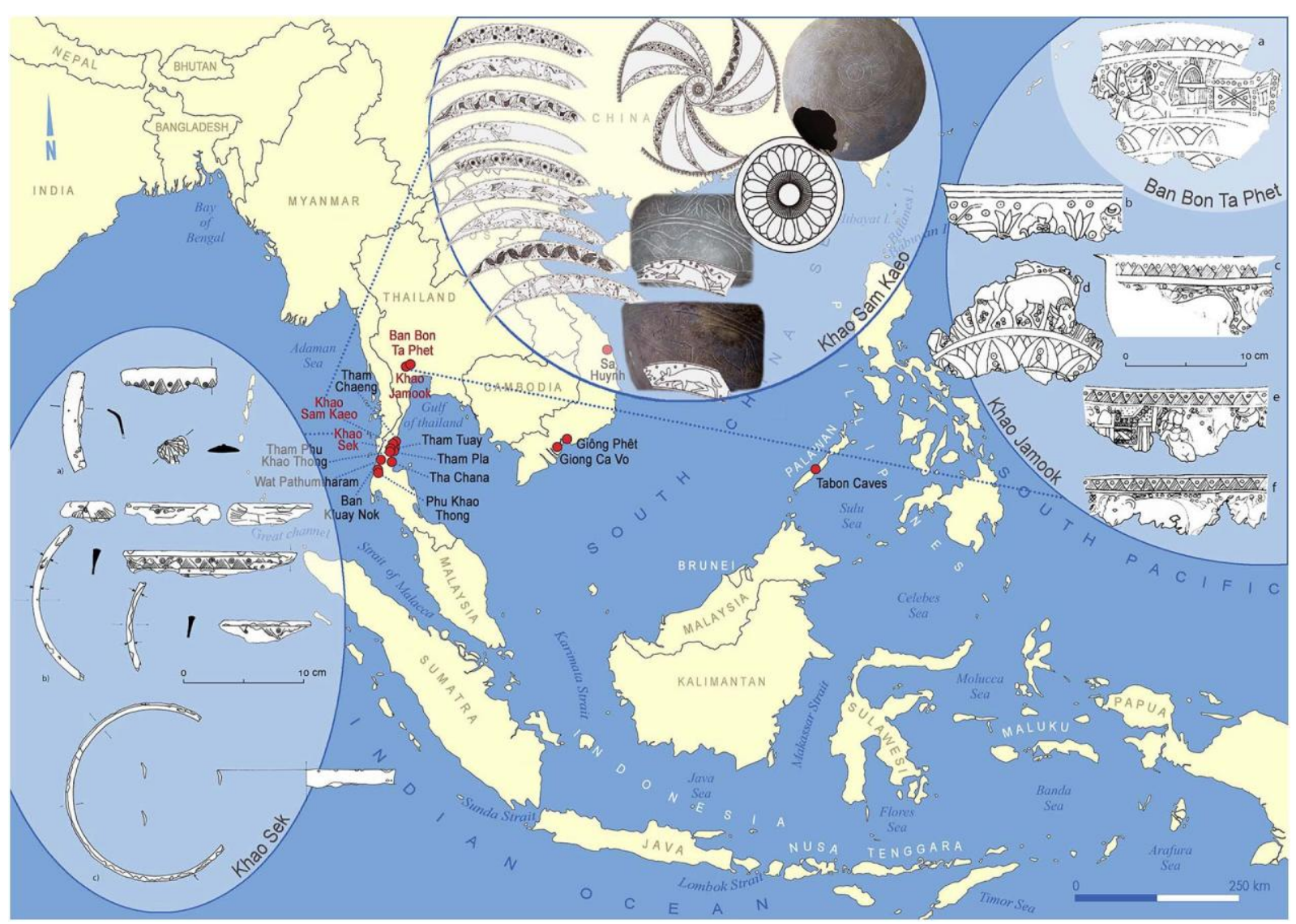

Fig. 2. Map indicating where decorated with Indian-inspired scenes high-tin bronze bowls were found (map UMR7055).

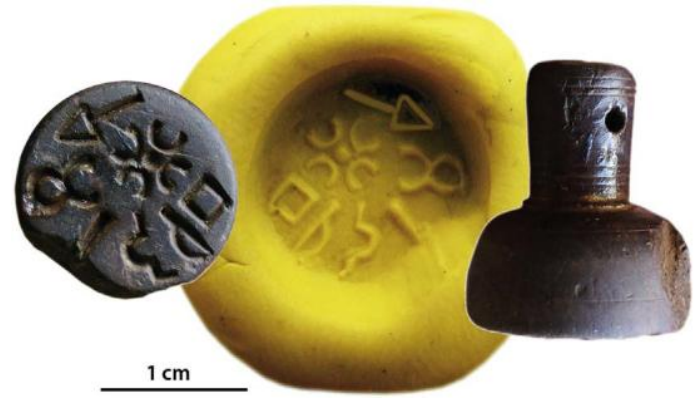

Fig. 3. Seal 1 (photo B. Bellina - private owner).

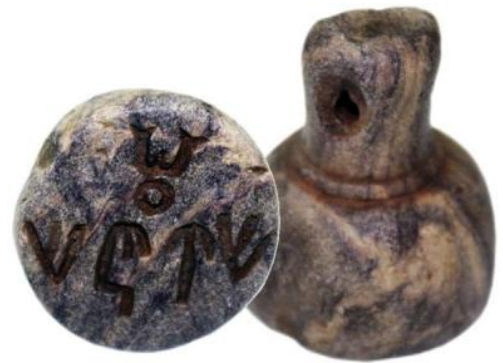

Fig. 4. Seal 2 (photos P. Petchey, planche E. Giraudet).
Hill 2 in the western part of the site near the river too (River Ta Taphao) was suspected to correspond to a burial zone.

\section{Discussion: inferences on political structure and craft standardisation}

In sum, Khao Sek and Khao Sam Kaeo are two contemporaneous settlements that show similar patterns of topography, construction modes, internal organisation and strikingly similar industrial models and products. The settlements were constructed on the same model and their hybrid industries are standardised. However, Khao Sek is distinct from Khao Sam Kaeo due to its more modest dimensions, the apparent absence of labour-intensive monumental constructions (such as surrounding walls and hydraulic systems) and of a cosmopolitan configuration. Unlike in Khao Sam Kaeo, we recovered no exogenous objects that could be associated to the settlement onsite of South Asians, such as the Indian Fine Wares (rouletted ware). Nor did we recovered evidence for north-Vietnamese and Chinese (Han ceramic, mirrors, seals) merchants. There are "Indian-influenced" objects, but no evidence for the presence of foreigners who at Khao Sam Kaeo, concentrated in the northern part of the site. The only possible evidence for the presence of foreigners consists of funerary jars (type KK-BJR), similar to those identified in Khao Sam Kaeo (KSK-BRJ), Tha Chana and the coastal cave of Tham Chaeng, and linked to the Philippines (Favereau, 2015, this issue). As opposed to Khao Sam Kaeo, there were very few foreign imports, those mostly consisting of some raw material such as glass and carnelian, agate and nephrite and thus no well-defined foreign socioprofessional compounds.

Regarding crafting industries, the two sites show undisputable similarities. Their hybrid industrial production systems combining local and foreign elements operated on the same models: in both sites, each industry, be it stone (Bellina, this volume), glass (Dussubieux and 


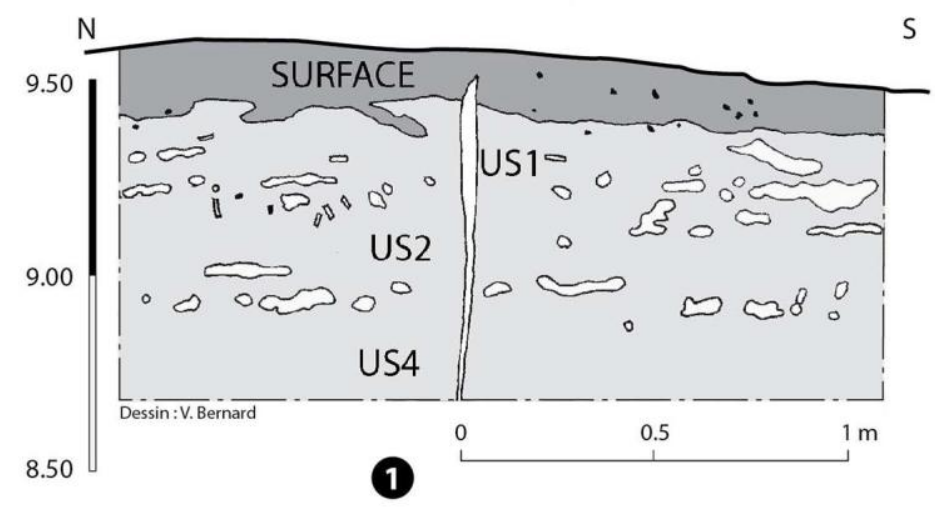

Fig. 5. 1. Eastern section of TP7 (drawing V. Bernard) 2. Urn and jar deposit US 3.1. 3. Urn and jar deposit US 3.2 (drawing: V. Bernard). 4. Section view of the restitution of the funerary jar (to the left). 5. Plan of the jar's content.

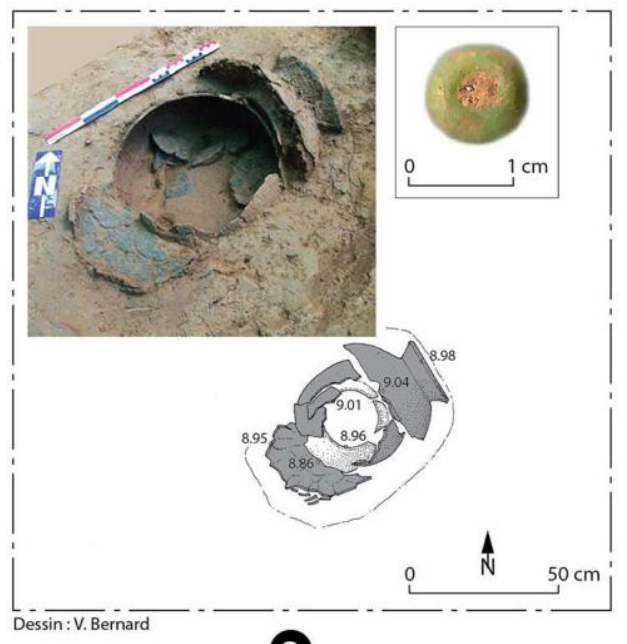

2

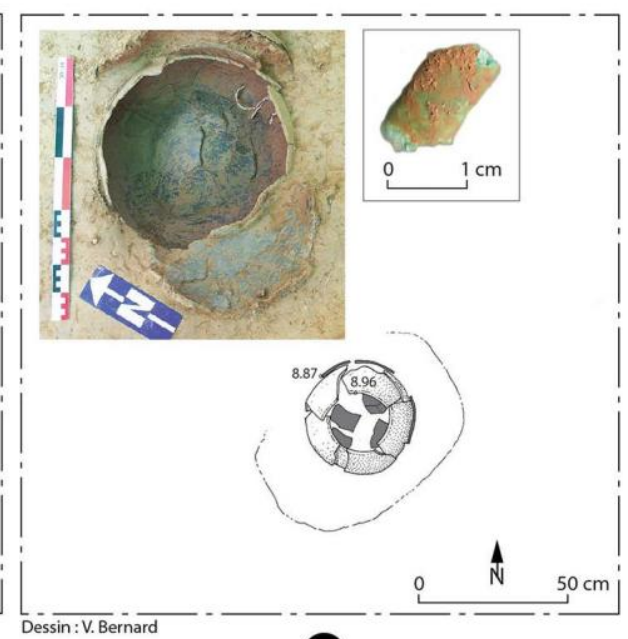

3

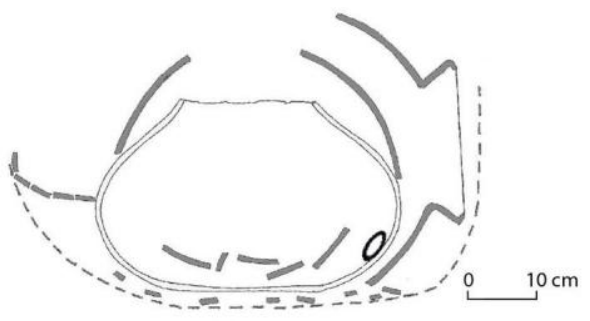

$(4)$

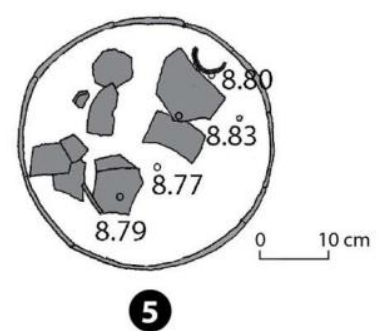

Bellina, this volume), ceramic (Favereau, this volume), bronze (Pryce and Bellina, this volume) or iron (Petchey et al., this volume) share the same "chaîne opératoire technique". These parallels in the "chaîne opératoire technique" begin with raw materials: several industries use similar supply networks. The change over time of imports is the same too, as this is especially clearly demonstrated with the different types of glass and glass products. Finally, a technological analysis which takes qualitative as well as quantitative data into account reveals that their final products are identical to a point that they could not be distinguished from one site to the other, with the exception of a few types (stone and glass beads) that could well results from special orders (see contributions this volume).

In both sites, each industry generated goods of the pan-regional type, i.e. South China Sea style, many of which are found in similar contemporary sites belonging to the same maritime networks. The technological reconstruction of the different industrial systems suggests that the populations of the two sites were related and that they were also in close contact, possibly with skilled artisans trained in foreign techniques circulating between the two sites. In addition, a few valuable objects made at Khao Sam Kaeo with foreign techniques may have been exported to Khao Sek, as in the case of some Indian-inspired ceramics. However, a few differences emerge too. The Dong Son drum found at Khao Sek appears to be a fake and is the only one reported there, whilst several authentic drums were recovered at Khao Sam Kaeo (see Pryce and Bellina, this volume). In addition, there is more diversity in the types of stone beads produced at Khao Sam Kaeo than in Khao Sek and the overall quality is slightly better in the first site than in the second (Bellina, this volume).

To me, the explanation of alliance-built hierarchic port-polities accounts best for the industries' standardisation, in particular for those involving similar foreign models, and for differences in the settlement size and complexity and the lesser quality of some of the products found at Khao Sek. Indeed, both settlements data and industries' reconstructions suggest a political structure which most plausibly resembled a hierarchically-based confederation of complementary port-polities aimed at exploiting and controlling both the local resources, tin in particular and possibly still archaeologically invisible organic materials from the forest, and the maritime and transpeninsular routes. Khao Sam Kaeo - larger, its urban organisation, of a cosmopolitan nature with socio-professional compounds, and with more and more diversified 
craft production than Khao Sek - was hierarchically superior for the period examined here. Khao Sam Kaeo, located along the "KraburiChumphon route", would have been the central place dealing with long-distance networks as defined by Manguin (2002, 2009). Khao Sek, near the mouth of the River Langsuan, controlled the route beginning in the region of Ranong on the west coast, passing through the Pakson, a confluent of the River Langsuan system (Ban Na Hyan site). Embarkations could have then have followed the coast to the mouth of the River Ta Thapao where boats could have navigated upstream to reach Khao Sam Kaeo. This centre would have constituted the central market at an "international" level where and foreign merchants settled and craftsmen concentrated.

But how did this confederation form? One possibility is that Khao Sek may have been created by Khao Sam Kaeo as an outpost to control the Langsuan river-system for its own benefice. Alternatively, it is possible also that regional first millennium exchange led to the development of small lowland polities at the mouths of the most significant river systems (Wisseman Christie, 1995) and that at some point during the 4 th-3rd c. BCE some of these formerly autonomous coastal polities temporarily confederated under the authority of a leading one, possibly Khao Sam Kaeo. Such a confederation may have been the result of Khao Sam Kaeo's polity' ambition to expand and make his polity into a central place able to collect and trade all regionally-produced goods. To do so, the polity he would have needed to capture more trading routes, themselves part of other river systems controlled by other polities. The ambitious leader would have had to subjugate other neighbouring polities' leaders. This may have entailed warfare. The presence of weapons within the iron assemblage (Petchey et al., this issue) may provide insights into this coercive atmosphere whereby coastal polities had to protect themselves against other similarly-ranked polities and possibly against other groups located inland or the so-called "sea nomads". Such frictions are well attested in the historical period. The leader may at least temporarily also have reached agreements on respective polity's rank and role without coercive means by providing honorific titles and gifts, a strategy well-described by ethno-historical sources. Extrapolating precisely from ethno-historical sources, I offer here some very tentative hypothesis to account for the circulation of artisans and the spread of similar chaînes operatoires within the polity, possibly from the leading one to its associated ones. The leader of the central polity could have permitted or ceded to allied leaders the means to maintain their own local networks of clients, thus promoting the supply of exchange goods. This diffusion of artisans, may have taken the form of an honorific "gift", sealing further bonds and making the secondary centre(s) dependent upon the central place. The transfer of artisans could have been a means for the central place polity's leader to weave a network of clients as well as to secure his marketplace supply, thus ensuring the wealth of his polity and its charisma. Artisans (or possibly only one), either those who initially settled at Khao Sam Kaeo or who were trained by them, could have moved to Khao Sek in the frame of these strategic political and economic bonds.

The value of craft products and of the means to produce them and their valued symbolic lexicon was understood at the regional level and spread both in the polities' hinterlands and in the region between similarly ranked allied trading polities in the South China Sea, such as those in southern Vietnam where ornaments show a similar style (Giong Ca Vo). Alternatively, the spread of craft systems may have resulted from raids and forced migrations of captured slaves and artisans, historical examples providing evidence for such practices between neighbouring competing polities (Beemer, 2009). This is especially relevant in the Southeast Asian context where kingdoms' power was estimated on the base of the amount of its people and not by the lands under their control. Craft producers, whether free or captured were the "artisans" of cultural changes and of the dissemination of pan-regional cultural traits, including material culture, in Southeast Asia. In any of those scenarios, artisans coming from various Asian horizons were valued political and economic agents contributing to strengthening the polity.
They also played an active role in cultural transfers and in crafting shared cultural references within the South China Sea, and also between the latter and polities on the other side of the Bay of Bengal. I believe that, as during the historical periods (Beemer, 2009; Reid, 1988: 101-103), the strategies of harnessing the specialists' expertise probably played a crucial role in the development of the region, through the emulation, in the Peninsula's trade-oriented polities, of specialties and techniques introduced from other trade-oriented polities in both South and Southeast Asia (Bellina, in press-c).

To sum up, the settlement and socio-technical reconstruction paints a picture of a confederation built over several river-basin systems, displaying some parallels with the upstream-downstream and Mandalatype of Malay polity described by Manguin for Srivijaya with Khao Sek here being part of the "umland"/periphery. The scenario provided here of the diffusion of artisans from the then central polity to allied polities as part of the strategy to secure the center's political and economic network could explain the diffusion of regional craft systems and a panregional material culture.

\section{Conclusion}

In conclusion and as demonstrated in the articles in this special issue, comparing Khao Sam Kaeo and Khao Sek settlements and industries provide strong evidence for a hierarchically-organised confederation of sites built over several river-basin systems to control transregional trade-routes and local resources. The assembling of possibly formerly autonomous polities which developed near the mouth of major river systems into this confederation resembles the multi-centred political model later observed at Srivijaya - that of a temporarily dominant central international market place connected by multiple fluvial and maritime networks to lower ranked trade polities or specialized sites.

At a micro-regional scale, it is reasonable to propose that the growth of the multi-centred Kra Isthmus polity may correspond to the extension of the settlement and erection of additional surrounding walls at Khao Sam Kaeo marked by the creation of foreign compounds in the northern part of the site (Bellina and Bernard, in press). At this time, Khao Sam Kaeo became the central place and Khao Sek and possibly other polities such as Phu Khao Thong (Ranong province) and others still to be identified as part of its periphery (or "umland"). This polity, with Khao Sam Kaeo having a predominant role for a certain period of time, thrived until about the $1 \mathrm{st} \mathrm{c}$. BCE-1rst $\mathrm{c}$. CE when activity declined in this part of the peninsula, maybe to the benefit of some other polity located further south (Chaiya, Tha Chana?).

To sum up, the Kra Isthmus with its rich local resources of tin and forest products and its compact and ancient trans-peninsular routes provides evidence of having been a site of experimentation in the development of urban forms (Bellina, in press-a, b, c) and political configurations of trading entities, which other maritime historical polities kept elaborating, especially in Malay-type polities.

Beyond, this proposed political reconstruction also has significant implications for understanding the diffusion of shared cultural models, here observed through the lenses of hybrid craft models and products. Developed in the Thai-Malay peninsula at the intersection of the Bay of Bengal and the South China Sea, hybrid craft systems and products may have diffused through the wider "hinterland" channels: they were transferred between trade polities which for a time were politically and economically bonded together. The transfer through this loosely tied multi-centred polity provides a tentative framework to explain the diffusion of similar pan-regional material culture within the "South China Sea Sphere of Interaction".

\section{Acknowledgments}

The author wishes to acknowledge David Bulbeck and Oliver Pryce for their comments on an earlier version of this article. The Franco-Thai 
archaeological Mission in the upper Thai-Malay peninsula was created in 2005. Its directors are B. Bellina (CNRS) and Professor Rasmi Shoocongdej (Silpakorn University) and from 2012 to 2014 C. Thongcharoenchaikit (National Science Museum). I express my deep gratitude to the "Sous-Commission des Fouilles of the French Ministry of Foreign Affairs, to the CNRS who have funded this research project. I also acknowledge the support of the Ecole francaise d'Extrême-Orient, the French Embassy in Thailand, the UMR CNRS 7528 'Mondes iranien et indien', the UMR CNRS 7055 'Préhistoire et Technologie', the National Research Council of Thailand and the Fine Arts Department, The National Museum of Chumphon, the Suthi Rattana Foundation and Saneh Pawkasin in Chumphon. I wish to thank each member of the team and collaborators: V. Bernard, C. Castillo, L. Dussubieux, A. Favereau, Hsiao-chun Hung and Yoshiyuki lizuka, Jitlada Inanchai, P. Petchey, T.O. Pryce, Sachipan Srikanlaya, Annabel Vallard. Finally, a special acknowledgement to Carla Sinopoli for inviting me to submit and for assisting in editing this special issue.

\section{References}

Agustijanto, I., 2013. The Pre-Srivijaya Period on the Eastern Coast of Sumatra. In: TjoaBonatz, M.L., Reinecke, A., Bonatz, D. (Eds.), Connecting Empires and States: Selected Papers from the 13th International Conference of the European Association of Southeast Asian Archaeologists. Volume 2 National University of Singapore Press. Aman ur Rahman, Falk, H., 2011. Seals, sealings and token from Gandhāra. In: Monographien zur Indischen Archäologie, Kunst und Philologie 21. 186 Reichert, Wiesbaden (no. TM 07.07.01)

Amrith, S., 2013. Crossing the Bay of Bengal - The Furies of Nature and the Fortunes of Migrants. Harvard University Press.

Andaya, L.Y., 2008. Leaves of the Same Tree. Trade and Ethnicity in the Straits of Melaka. University of Hawai'i Press, Honolulu.

Andaya, B.W., Andaya, L.Y., 2015. A History of Early Modern Southeast Asia, 1400-1830. Cambridge University Press.

Bacus, E., 2003. Style of alliance?: decorated Earthenwares in late prehistoric and protohistoric Philippine polities. In: Miksic, J. (Ed.), Earthenwares in Southeast Asia Singapore. Singapore University Press, pp. 39-51.

Beemer, B., 2009. Southeast Asian slavery and slave-gathering warfare as vector for cultural transmission: the case of Burma and Thailand. Historian 71 (3), 481-506.

Bellina, B., 2001. Témoinages archéologiques d'échanges entre l'Inde et l'Asie du Sud-Est: morphologie, morphométrie et techniques de fabrication des perles en agate et en cornaline. (PhD Thesis) Université Paris III, Paris.

Bellina, B., 2003. Beads, social change and interaction between India and Southeast Asia Antiquity 77 (296), 285-297.

Bellina, B., 2007. Cultural Exchange Between India and Southeast Asia: Production and Distribution of Hard Stone Ornaments, VIc. BC-VIc. AD. Editions de la Maison des sciences de l'Homme, Paris.

Bellina, B., 2014. Maritime Silk Roads' ornament industries: socio-political practices and cultural transfers in the South China Sea. Cambridge Journal of Archaeology 24 (3), 345-377.

Bellina, B., 2017a. Khao Sam Kaeo: a cosmopolitan port-city or city-state in the South China Sea. In: Bellina, B. (Ed.), Khao Sam Kaeo: A Late Prehistoric Early Port-City Between the Indian Ocean and the South China Sea. Ecole française d'Extrême-Orient, Paris (in press)

Bellina, B., 2017b. Southeast Asian evidence for early maritime exchange and trade-related polities. In: Higham, C.W.F., Kim, N. (Eds.), The Oxford Handbook of Southeas Asian Archaeology. Oxford University Press (in press).

Bellina, B., 2017c. Conclusion. In Bellina, B. (a. in press). "Khao Sam Kaeo: a cosmopolitan port-city or city-state in the South China Sea.”. In: Bellina, B. (Ed.), Khao Sam Kaeo: A Late Prehistoric Early Port-City Between the Indian Ocean and the South China Sea. Ecole française d'Extrême-Orient, Paris (in press).

Bellina, B. (Ed.), 2017. Khao Sam Kaeo: A Cosmopolitan Port-City or City-State in the South China Sea. Ecole française d'Extrême-Orient, Paris (in press).

Bellina, B., Bernard, V., 2017. The settlement of Khao Sam Kaeo. In: Belllina, B. (Ed.), Khao Sam Kaeo: A Cosmopolitan Port-City or City-State in the South China Sea. Ecole française d'Extrême-Orient, Paris (in press).

Bellina, B., Glover, I.C., 2004. The archaeology of early contacts with India and the Mediterranean World from the fourth century BC to the fourth century AD. In: Glover, I.C., Bellwood, P. (Eds.), Southeast Asia, From the Prehistory to History. Routledge/Curzon Press, London, pp. 68-89.

Bellina, B., Epinal, G., Favereau, A., 2012. Caractérisation préliminaire des poteries marqueurs d'échanges en Mer de Chine Méridionale à la fin de la préhistoire. Archipe $84,7-33$.

Bellina, B., Silapanth, Praon, Chaisuwan, Boonyarit, Thongcharoenchaikit, Cholawit, Allen, Jane, Bernard, Vincent, Borell, Brigitte, Bouvet, Phaedra, Castillo, Cristina, Dussubieux, Laure, LaClair, Julie Malakie, Srikanlaya, Sachipan, Peronnet, Sophie, Pryce, Thomas Oliver, 2014. The development of coastal polities in the upper Thai Malay peninsula in the late first millennium BCE. In: Revire, N., Murphy, S. (Eds.), Before Siam Was Born: New Insights on the Art and Archaeology of Pre-Modern Thailand and Its Neighbouring Regions. River Books, Bangkok, pp. 68-89.
Press, Honolulu.

Blench, R., 2017. Regional Perspectives. In: Calanca, P., Yi-ch'ang, Liu, Muyard, F. (Eds.), Taiwan Maritime Landscapes from Neolithic to Early Modern Times. EFEO, Institute of History and Philology, Academia Sinica (in press).

Boonyarit Chaisuwan, 2011. Early contacts between India and the Andaman coast in Thailand from second century BCE to eleventh century CE. In: Manguin, P.-Y., Mani, A., Wade, G. (Eds.), Early Interactions Between South and Southeast Asia. Reflections on Cross-cultural Exchange. ISEAS Publishing and Manohar, Singapore and New Delhi, pp. 83-111.

Borell, B., 2017. Stone Seals and Intaglios from Khao Sam Kaeo. In: Bellina, B. (Ed.), Khao Sam Kaeo An Early Port-City between the India Ocean and the South China Sea. Mémoires Archéologiques 28. Ecole française d'Extrême-Orient, pp. 587-626 (in press)

Bourdonneau, E., 2010. Réhabiliter le Funan. Oc Eo ou la première Angkor. Bulletin de l'Ecole française d'Extrême-Orient 94 (2007), 111-158.

Bouvet, P., 2011. Preliminary study of Indian and Indian style wares from Khao Sam Kaeo (Chumphon, Peninsular Thailand), fourth-second centuries BCE. In: Manguin, P.-Y., Mani, A., Wade, G. (Eds.), Early Interactions Between South and Southeast Asia. Reflections on Cross-cultural Exchange. ISEAS Publishing and Manohar, Singapore and New Delhi, pp. 47-81.

Bouvet, P., 2012. Interactions culturelles entre l'Asie du Sud-Est et l'Inde aux 4e-2e s. av. J.-C.: étude technologique des céramiques de Khao Sam Kaeo (Thaïlande péninsulaire, province de Chumphon). Préhistoire et technologies. University Paris X, Nanterre $(\mathrm{PhD})$.

Brandão, A., et al., 2016. Quantifying the legacy of the Chinese Neolithic on the maternal genetic heritage of Taiwan and Island Southeast Asia. Hum. Genet. http://dx.doi.org/ 10.1007/s00439-016-1640-3.

Bronson, B., 1977. Exchange at the upstream and downstream ends: notes towards a functional model of the coastal state in Southeast Asia. In: Hutterer, K.E. (Ed.), Economic Exchange and Social Interaction in Southeast Asia: Perspectives From Prehistory, History and Ethnography, Michigan Papers on South and Southeast Asia No. 13, Center for South and Southeast Asian Studies. University of Michigan, Ann Arbor (MI), pp. 39-52.

Bronson, B., 1990. Glass and beads at Khuan Lukpad, Southern Thailand. In: I. C., Glover, E. (Eds.), Southeast Asian Archaeology 1986. S-561. British Archaeological Reports, Oxford, pp. 213-229.

Bulbeck, D., 2008. An integrated perspective on the Austronesian diaspora: the switch from cereal agriculture to maritime foraging in the colonisation of Island Southeast Asia. Aust. Archaeol. 67, 31-51.

Bulbeck, D., 2014. The chronometric Holocene archaeological record of the Southern Thai-Malay Peninsula. International Journal of Asia-Pacific studies 10 (1), 112-162 January 2014.

Calo, A., 2014. Trails of Bronze Drums Across Early Southeast Asia: Exchange Routes and Connected Cultural Spheres. Institute of Southeast Asian Studies, Singapore (229 pages)

Calò, A., et al., 2015. Sembiran and Pacung on the north coast of Bali: a strategic crossroads for early trans-Asiatic exchange. Antiquity 89 (344), 378-396.

Carter, A.K., 2015. Beads, exchange networks and emerging complexity: a case study from Cambodia and Thailand (500 BCE-CE 500). Camb. Archaeol. J. 733-757.

Carter, A.K., Dussubieux, L., 2016. Geologic provenience analysis of agate and carnelian beads using laser ablation-inductively coupled plasma-mass spectrometry (LA-ICPMS): a case study from Iron Age Cambodia and Thailand. J. Archaeol. Sci. Rep. 6 (2016), 321-331.

Castillo, C., 2013. The Archaeobotany of Khao Sam Kaeo and Phu Khao Thong: The Agriculture of Late Prehistoric Southern Thailand. (Unpublished PhD thesis) Institute of Archaeology, University College London.

Castillo, C., The archaeobotany of Khao Sek. Archaeological Research in Asia (this issue).

Castillo, C., Bellina, B., Fuller, D.Q., 2016. Rice, beans and trade crops on the early maritime silk route in Southeast Asia. Antiquity 90 (353), 1255-1269.

Dung, N.K., 2017. The Sa Huynh Culture in Ancient Regional Trade Networks: A Comparative Study of Ornaments. In: Piper, P.J., Matsumura, H., Bulbeck, D. (Eds.), New Perspectives in Southeast Asian and Pacific Prehistory. 45. pp. 311-332 Terra Australis.

Dussubieux, L., Bellina, B., 2017. Glass from an early Southeast Asian producing and trading centre. In: Belllina, B. (Ed.), Khao Sam Kaeo: A Cosmopolitan Port-City or City-State in the South China Sea. Ecole française d'Extrême-Orient, Paris (in press).

Dussubieux, L. and Bellina, B., Glass ornament production and trade polities in the UpperThai Peninsula during the Early Iron Age. Archaeological Research in Asia (this issue).

Dussubieux, L., Gratuze, B., 2010. Glass in Southeast Asia. In: Bellina, B., Bacus, L., Pryce, T.O., Wisseman Christie, J. (Eds.), 50 Years of Archaeology in Southeast Asia: Essays in Honour of Ian Glover. River Books, Bangkok, pp. 244-257.

Favereau, A., 2015. Interactions et modalités des échanges en Mer de Chine méridionale (500 avant notre ère - 200 de notre ère): approche technologique des assemblages céramiques. (Thèse de doctorat) Muséum National d'Histoire Naturelle, Paris, France.

Favereau, A., The analysis of Khao Sek pottery: insight into the circulations and the politico-economic context of the Thai-Malay Peninsula (500 BC - AD 200). Archaeological Research in Asia (this issue).

Favereau, A., Bellina, B., 2016. Thai-Malay Peninsula and South China Sea networks (500 BC - AD 200) based on a reappraisal of "Sa Huynh-Kalanay" ceramics. Quat. Int. $30,1-9$.

Flavel, A., 1997. Sa-Huynh Kalanay? Analysis of the Prehistoric Decorated Earthenware of South Sulawesi in an Island Southeast Asian Context. (A thesis submitted in partial fulfilment of the requirements for the degree of Bachelor of Science (Honours)) Centre for Archaeology University of Western Australia (October 1997. 231 pages)

Glover, I.C., 2015. Champa and its relations to preceding iron age cultures. Văn hóa Champa và mối quan hệ với các nền văn hóa thời đại đồ sắt trước đó. In: Reinecke, 
Andreas (Ed.), Perspectives on the Archaeology of Vietnam. Toàn cảnh khảo cổ học Việt Nam. German Archaeological Institute, Bonn, pp. 157-174.

Gupta, S., 2005. The Bay of Bengal interaction sphere (1000 BC - AD 500). Bulletin of the Indo-Pacific Prehistory Association 25, 21-30.

Hung, H.-C., 2017. Nephrite and mica industries: a link towards the Austronesian world In: Bellina, B. (Ed.), Khao Sam Kaeo: A Late Prehistoric Early City Between the Indian Ocean and the South China Sea. Editions de l'Ecole française d'Extrême-Orient, Paris (in press).

Hung, H.-C., Bellwood, P., 2010. Movement of raw materials and manufactured goods across the South China sea after 500 BCE: From Taiwan to Thailand, and back. In: Bellina, B., Bacus, E.A., Pryce, T.O., Wisseman Christie, J. (Eds.), 50 Years of Archaeology in Southeast Asia. Essays in Honour of Ian GloverBangkok. River Books, pp. 234-245.

Hung, H.-C., et al., 2007. Ancient jades map: 3,000 years of prehistoric exchange in Southeast Asia. Proceedings of the National Academy of Sciences 104 (50), 745 75019.

Hung, H.-C., et al., 2013. Coastal connectivity: long-term trading networks across the South China Sea. Journal of Coastal and Island Archaeology 8, 384-404.

Junker, L.L., 1990. Long Distance Trade and the Development of Socio-political Complexity in Philippine Chiefdoms of the First Millenium to Mid Second Millennium AD, Michigan, Ann Arbor.

Junker, L.L., 1993. Crafts goods specialization and prestige goods exchange in the Philippine chiefdoms of the 15th and 16th centuries. Asian Perspect. 32 (1), 1-35.

Junker, L.L., 1999. Raiding, Trading, and Feasting - the Political Economy of Philippine Chiefdoms. University of Hawaii Press, Honolulu.

Junker, L.L., 2006. Population dynamics and urbanism in pre-Modern Island Southeast Asia. In: Storey, G. (Ed.), Urbanism in the Pre-industrial World: Cross-cultural Approaches. University of Alabama Press, Tuscaloosa, Ala, pp. 186-215.

Kim, N.C., 2013. Lasting monuments and durable institutions: labor, urbanism, and statehood in northern Vietnam and beyond. J. Archaeol. Res. 21, 217-267.

Kim, N.C., 2015. The Origins of Ancient Vietnam. Oxford University Press, Oxford.

Kulke, H., 1986. The Early and the Imperial Kingdom in Southeast Asian History. In Marr, D.G., Milner, A.C. (Eds.), South-East Asia in the $9^{\text {th }}$ to $14^{\text {th }}$ Centuries. Institute of Southeast Asian studies Singapore and the Regional School of Pacific studies, Australian National University, pp. 1-22.

Kulke, H, 1990. Indian colonies, Indianization or cultural convergence? Reflections on the changing image of India's role in South-East Asia. In: Schulte Nordholt, H. (Ed.), Onderzoek in Zuidoost-Azie. Rijksuniversiteit te Leiden, Leiden, pp. 8-32.

Kulke, H., 1993. Kadåtuan Srivijaya-empire or Kraton of Srivijaya? A reassessment of the epigraphical evidence. BEFEO 80, 159-181.

Leong Sau Heng, 1990. Collecting centres, feeder points and entrepôts in the Malay Peninsula, 1000 B.C.-A.D. 1400. In: Kathirithamby-Wells, J., Villiers, J. (Eds.), The Southeast Asian Port and Polity. Rise and Demise. Singapore University Press, Singapore, pp. 17-38.

Lieberman, V., 2003. Strange parallels. Integration of the mainland: Southeast Asia in global context, c. 800-1830. In: Studies in Comparative World History. Cambridge University Press, Cambridge.

Lombard, D., 1970. Pour une histoire des villes du Sud-Est asiatique. Annales, Économies, Sociétés, Civilisations 24 (4), 842-856.

Lombard, D., 1988. Le sultanat malais comme modèle socio-économique. In: Lombard, D., Aubin, J. (Eds.), Marchands et hommes d'affaires asiatiques dans l'Océan Indien et la Mer de Chine XIIIe-XXe siècles. École des hautes études en sciences sociales, Paris, pp. 117-124.

Loofs-Wissowa, 1991. Dongson drums: instruments of shamanism or regalia ? Arts Asiatiques 46, 39-49.

Manguin, P.-Y., 2000. City-states and city-state cultures in pre-15th century Southeast Asia. In: Hansen, M.H. (Ed.), A Comparative Study of Thirty City-State Cultures. An Investigation Conducted by the Copenhag Polis Centre. C. A. Reitzels Forlag, Copenhagen, pp. 409-416.

Manguin, P.-Y., 2002. The amorphous nature of coastal polities in insular Southeast Asia: restricted centres, extended peripheries. Mousson 5, 73-99.

Manguin, P.-Y., 2004. The archaeology of early maritime polities of Southeast Asia. In: Bellwood, P., Glover, I.C. (Eds.), Southeast Asia. From Prehistory to History. RoutledgeCurzon, London New York, pp. 282-313.

Manguin, P.-Y., 2009. Southeast Sumatra in protohistoric and Srivijaya times: upstreamdownstream relations and the settlement of the peneplain. In: Bonatz, D., Miksic, J., Neidel, D., Tjoa-Bonatz, M.L. (Eds.), From Distant Tales: Archaeology and Ethnohistory in the Highlands of Sumatra. Cambridge Scholars Publishing, pp. 434484.

Manguin, P.-Y., Khai, V.S., 2000. Excavations at the Ba The Oc Eo complex (Vietnam): a preliminary report on the 1998 campaign. In: Lobo, W., Riman, S. (Eds.), Southeast Asian Archaeology 1998. Hull, Centre of Southeast Asian Archaeology, pp. 107-121.

Miksic, J.N., 1979. Archaeology, Trade and Society in Northeast Sumatra. pp. 334 Thesis presented to the Faculty of the Graduate School of cornell University.

Miksic, J., 2000. Heterogenic cities in premodern Southeast Asia. World Archaeol. 32 (1), 106-120.
Mokhtar Naizatul Akma Mohd, 2009. The Discovery of Iron Smelting in Sg. Batu, Lembah Bujang, Kedah IN IPPA 2009 Program and Abstracts, November 29th December 5th 2009. Institute of Archaeology, VASS.

Mokhtar Naizatul Akma, Mokhtar Saidin and Jeffrey Abdullah. The Ancient Iron Smelting in $\mathrm{Sg}$. Batu, Bujang Valley, Kedah, (unpublished, 15 pages, undated).

Murillo-Barroso, et al., 2010. Khao Sam Kaeo - an archaeometallurgical crossroads for trans-Asiatic technological traditions. J. Archaeol. Sci. 37, 1761-1772.

Petchey, P., et al., The Discovery of a late prehistoric iron workshop at Khao Sek, Chumphon Province, Thai-Malay Peninsula. Archaeological Research in Asia (this issue).

Petchey, P., Bellina, B., Pryce, T.O.Innanchai J., 2017. A late prehistoric iron smithing workshop and associated iron industry at the port settlement of Khao Sek, Thai-Malay Peninsula. Archaeological Research in Asia (this issue).

Pryce, T.O and Bellina, B., High-tin bronze bowls and copper drums: Non-ferrous archaeometallurgical evidence for Khao Sek's involvement and role in regional later 1st millennium BC Thai-Malay Peninsula exchange systems. Archaeological Research in Asia (this issue).

Pryce, T.O., Baron, S., Bellina, B., Bellwood, P., Chang, N., Chattopadhyay, P., Dizon, E., Glover, I.C., Hamilton, E., Higham, C.F.W., Kyaw, A.A., Laychour, V., Natapintu, S., Nguyen, V., Pautreau, J.-P., Pernicka, E., Pigott, V.C., Pollard, A.M., Pottier, C., Reinecke, A., Sayavongkhamdy, T., Souksavatdy, V., White, J., 2014. More questions than answers : the Southeast Asian Lead Isotope Project 2009-2012. J. Archaeol. Sci. 42, 273-294.

Pryce, T.O., et al., 2017. The metallurgical industries. In: Bellina, B. (Ed.), Khao Sam Kaeo: A Late Prehistoric Early City Between the Indian Ocean and the South China Sea. Editions de l'Ecole française d'Extrême-Orient, Paris (in press).

Reid, A., 1988. Southeast Asia in the Age of Commerce 1450-1680. Volume One: The Lands Below the Winds. Silkworm Books, Chiang Mai.

Reid, A., 1988. Southeast Asia in the age of commerce 1450-1680. In: Volume one: The lands below the winds. London Yale University Press, New Haven.

Reid, A., 2000. The culture of Malay-speaking city-states of the fifteenth and sixteenth centuries. In: Hansen, M.H. (Ed.), A Comparative Study of Thirty City-State Cultures. An Investigation Conducted by the Copenhag Polis Centre, Copenhagen, C. A. Reitzels Forlag, pp. 417-429.

Soares, P., et al., 2008. Climate change and postglacial human dispersals in Southeast Asia. Mol. Biol. Evol. 25, 1209-1218. http://dx.doi.org/10.1093/molbev/msn068.

Soares, P., et al., 2016. Resolving the ancestry of Austronesian-speaking populations. Human Genetic 135, 309-326.

Solheim, W.G., 2006. Archaeology and culture in Southeast Asia: Unravelling the Nusantao. With Contributions From D. Bulbeck and Ambika Flavel. The University of the Philippines Press, Quezon City.

Stark, M., 2006. Pre-Angkorian settlement trends in Cambodia's Mekong Delta and the Lower Mekong Archaeological Project. Bulletin of the Indo-Pacific Prehistory Association 26, 98-109.

Stark, M., 2015. Southeast Asian urbanism: from early city to Classical state. The Cambridge World History: Volume III. In: Early Cities in Comparative Perspective, 4000 BCE - 1200 CE. Cambridge University Press, pp. 74-93.

Sukanya Baonoed, 2016. Non Nong Hor: The Production Site of Bronze Drum in Thailand. Abstracts of the $2^{\text {nd }}$ SEAMEO SPAFA International Conference on Southeast Asian Archaeology. $30^{\text {th }}$ May-2 $2^{\text {nd }}$ June 2016. Amari Watergate Hotel, Bangkok.

Tambiah, S.J., 1977. The galactic polity: the structure of traditional kingdoms in Southeast Asia. Ann. N. Y. Acad. Sci. 293, 69-97.

Tarling, N., 1992. The Cambridge History of Southeast Asia, Volume 1: From Early Times to c. 1800 . University of Auckland.

Veraprasert, M., 1992. Khlong Thom: an ancient bead manufacturing locations and an ancient Entrepôt. In: Glover, I.C., Suchitta, P., Villiers, J. (Eds.), Early Metallurgy, Trade and Urban Centres in Thailand and Southeast Asia. White Lotus, Bangkok, pp. 149-161.

Wisseman Christie, J., 1984-1985. Trade and early state formation in maritime Southeast Asia: Kedah and Srivijaya. Jabat 13, 43-56.

Wisseman Christie, J., 1990. Trade and state formation in the Malay Peninsula and Sumatra, 300 BC - AD 700. In: Kathirithamby-Wells, J., Villiers, J. (Eds.), The Southeast Asian Port and Polity: Rise and Demise. Singapore University Press, Singapore, pp. 39-60.

Wisseman Christie, J., 1995. State formation in Early Maritime Southeast Asia: a consideration of the theories and the data. Bijdragen tot de Taal-, Land- en Volkenkunde 151 (2), 235-288.

Wolters, O., 1982. History, Culture and Region in Southeast Asian Perspectives. Institue of Southeast Asian Studies, Singapore.

Yamagata, M., 1997. Formation of Lin Yi; derived from archaeological materials. Journal of Southeast Asian Archaeology 17 (6), 168-184.

Yamagata, M., 2007. The early history of Lin-i viewed from archaeology. Acta Asiatica 92, $1-30$.

Yamagata, M., Glover, I.C., 1994. Excavations at Buu Chau Hill, Tra Kieu, Vietnam 1993. The Journal of Southeast Asian Archaeology 14, 48-57. 